\title{
Getting the priorities right
}

\author{
Promises for UK science must be backed up by long-term plans.
}

Ostensibly, it was good news for UK science in the government's Autumn Statement made earlier this month by Chancellor of the Exchequer, George Osborne. Significant investment is planned in some bright new ideas - yet the promises have done little to alleviate a sense of anxious uncertainty in the British scientific community.

Included in a wide package of measures intended to push forward the country's economic recovery were several specific plans for scientific infrastructure and collaboration - reflecting, it seems, Osborne's claim that "science is a personal priority of mine". At the top of the list is an investment of $£ 270$ million, over five years, to establish a UK network of quantum technology centres that will develop the applications of quantum research and encourage their exploitation in industry. Nearly $£ 11$ million will be spent to establish the Higgs Centre at the University of Edinburgh - named for new Nobel laureate Peter Higgs and concerned with the processing of 'big data' for the astronomy and particle-physics communities, but also industry-linked through the intention to support start-up companies in data handling.

The Emerging Powers Research Fund - to be worth $£ 375$ million over five years - was welcomed by Royal Society President Paul Nurse for its support of the collaboration of UK scientists with "the emerging scientific powers [who] bring their own skills to the table, in many cases backed by large-scale investment." And the $£ 80$-million Global Collaborative
Space Programme has the specific aim of fostering working relationships between UK space scientists and companies and their counterparts in China, India and Russia.

The independent science-advocacy group Campaign for Science and Engineering (CaSE; http://sciencecampaign.org.uk) has similarly welcomed the Chancellor's plans but has also highlighted the need to back up the proposed capital investment "by matching it with operational costs in a sustainable way". British scientists already have bitter experience of the government's failure to do such accounting. In a report, published in November 2013, the House of Lords Science and Technology Committee (a group drawn from the upper house of parliament, and chaired by zoologist John Krebs) cites the example of ISIS, the pulsed neutron and muon source at the Rutherford Appleton Laboratory in Oxfordshire: despite the investment of $£ 145$ million in developing and expanding this facility, there has since been insufficient cash to run it at more than twothirds of its capacity, delaying experiments that impact many fields of science.

The Lords' report stresses "key shortcomings" - "the lack of a longterm strategy and investment plan for scientific infrastructure; and a failure to provide adequately for operational costs at infrastructure facilities" - that should be addressed by the governmental Department of Business, Innovation and Skills (BIS), which is responsible for science, "to ensure that resources are used to maximum effect and the UK's scientific infrastructure remains internationally competitive" (http://go.nature.com/1M8dFU).

Yet, as part of the goverment's acrossthe-board spending cuts, BIS is set to suffer a $£ 304$ million drop in its resources by 2016. Sarah Main, director of CaSE, worries that "this may have a damaging effect on our research capability. Our researchers are already struggling with a flat cash budget since 2010 that has been eroded by $£ 266$ million by deflation to date.”

For scientists, it's a confusing picture of promised investment and inescapable cuts - and one that is even more clouded by the process of the Research Excellence Framework (REF), which is assessing the strength of research across British highereducation institutions and will be the basis for the allocation of funding. The REF encompasses all research in the period 2008-2013 and its outcome, in 2014, will be in the form of star-ratings (from four stars, down to 'unclassified') for each institution. Already, however, the REF has met with substantial criticism from researchers for certain of its rules that would seem to provoke 'gaming' of the system, and for its now-notorious stipulation that researchers must demonstrate the 'impact' of their work.

In his Autumn Statement, Chancellor Osborne also promised the publication of a 'science and innovation strategy' with the next Autumn Statement in 2014. British scientists - and those scientists around the world with whom they are encouraged to collaborate - will want to see clear priorities set, and supported.

\section{Back to the Futures}

\section{The science-fiction strand 'Futures' returns to Nature Physics in this issue.}

For several years now, our sister title Nature has published each week, among its many pages of science fact, one page devoted to science fiction. The 'Futures' stories - by amateur and professional science-fiction writers, scientists and non-scientists - have become a regular, popular fixture, and also expanded into the pages of this journal for a couple of years. We're pleased to say that now Futures is back in Nature Physics turn to the last page of this issue for our first piece of the new season, from Steven L. Peck.
Futures in Nature - like the research and comment that journal publishes - have reflected all of science: expect Futures in Nature Physics to take their inspiration from physics and physicists. Our stories will also be collated with the Nature ones in our archives (http://www.nature.com/futures), and on the Futures Facebook page (http://go.nature.com/mtoodm), which now has more than 11,000 followers. There's a growing band of fans on Twitter too (@NatureFutures).
An anthology of Futures, originally published in unfuturistic print in 2008, is about to be released as an e-book. It's titled 'Futures 1', from which readers should rightly infer that a further edition, 'Futures 2', and even 'Futures 3', will follow later in 2014.

All Futures stories are available free of charge, and should you feel inspired you may submit your own futuristic vision to futures@nature.com (although do please read the guidelines first at http://go.nature.com/p8T8eZ). 